340 物質・材料データベースを用いた規則性の抽出

\title{
Investigation of Regularity from a Comprehensive Material Database
}

○茂木厚史（東大）、岡伸人（東大）、金田保則（東大）、陳迎（東大）、岩田修一（東大）

Atsushi MOTEKI, Nobuto OKA, Yasunori KANETA, Ying CHEN, Shuichi IWATA

School of Engineering, The University of Tokyo

\section{1. はじめに}

近年、過去の研究の澵大な蓄積と情報技術の進步により様々な大 規模材料データベースが開発・整撑されつつある。材料設計におい てこのようなデータベースを用い、效率よく新材料を発見する事を 可能とする様な材料設言十璄境の実現が強く望まれている。また同時 に新材料発見のための手法の開発も望まれているが、その中で、材 料デー夕群中に隠されている規則性の発見やその利用が重要であ ると考えられている。

Villars 等は二元采化合物の構成元素と結晶構造との関係をマッ プにより示しだリ。これは先に述べた隠された規則性の発見を目的 としたものである。彼らは大量の二元采化合物の結晶構造デ一夕の うち特に数の多い $1: 1$ の成分組成を持つ $\mathrm{AB}$ 化合物に着目し、その 構成元素と結晶楼造との関俰について解析を行った。マップの軸と してはMendeleev Number(MN)の最大值や比を用いた MN とは 性質が似かよった元素ができるだけ近くに並ぶように周期律表の 各元素を並へなおし順序付けを行った際の番号である[。っこれよよ り、同族の元素には、連続した番号か割り振られる。また彼等は結 晶構造の分類として AET (Atomic Environment Type)を用いた。 AET とは結晶中のある原子を中心とし、その周りの近接原子の配

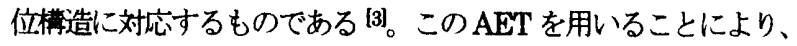
原子配置パターンの規則性抽出成功した[1,4]。

しかし、彼らの研究は 1:1 の成分組成でさらに各化合物には 1 種 類のAET しか存在しない 結晶構造(Single AET)のみを扱っており、 その他の組成や結晶棈造に対して、彼らの手法による分類・マップ 作成が有効であるか壮不明である。今回、我々は1：3の組成を持 つ化合物を対象とし、Villars 等と同棣に MN と AET を用いたマ ップ表現による規則性探索を行う。これにより、1:1の SingleAET のみならず、幅広、物質群に対し、上記の様なマップ表現による規 則性探索が有効であるかどうかを明らかにするのが本研究の目的 ある。

\section{2. 方法}

今回我々は、材料データべース (DB)として、Pauling File (PF)

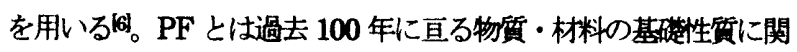
するデータを格納したデータベースと、そのデータを閲筧・検索す るためのツール群からなるデータシステムである。2003 年現在、 このDB (Binary Editon) には二元系の合金、金属閒化合物、無
機材料の状態図、結晶構造、物性値などのデータが格納されている 大規模材料データベースである。その中に約 28,000 件の結晶構造 に関するエントリーが格納されている。

規則性の探卖は、PFに格納されているデータから 1:3 化合物の 結晶構造データを抽出して行う。抽出された二元系の個々の物質に は、結晶学上異なるサイトが袮数存在するにもかかからず、1 種類 の AET しか含んでいない構造を持っているものがある(Single $\mathrm{AET}$ 。例えば、Cu3Au 型粠造は 1a,3c という 2 つのサイトを含ん でいるが、どちらのサイトも同じ 12-b といら AET である(Fig1)。 これをSingleAET と呼ぶ。同様に2 種のAETを含む結晶粠造を Double AET と呼び、 $\mathrm{Cr}_{3}$ Si 型構造はその代表例である。1:3の 組成を持化合物はPFから 1622 件抽出できたここうち が Single AET, 441 件が Double AET, 464 件が Triple AET であっ た (最大Octuple)。今回は特にデータ数の多いSingle AET に注目 することにする。

Table 1,2 は Single AET と Double AET に対してデータ数の多 い上位5つの結晶粠造型を抜き出したものである。さらに代表的な 図をFig. 1 に示す。今回我々はTable 1 に示したデー夕に対して規 則性探索を試みる事にする。

Table 1. The number of phases for 5 most common AETs in Single AET.

\begin{tabular}{ccc}
\hline Structure Type & AET(single) & Number of Phases \\
\hline $\mathrm{Cu}_{3} \mathrm{Au}$ & $12 \cdot \mathrm{b}$ & 278 \\
$\mathrm{Mg}_{3} \mathrm{Cd}$ & $12 \cdot \mathrm{d}$ & 71 \\
$\mathrm{Cu}$ & $12 \cdot \mathrm{b}$ & 47 \\
$\mathrm{BiF}_{3}$ & $14 \cdot \mathrm{b}$ & 42 \\
$\mathrm{~W}$ & $14 \cdot \mathrm{b}$ & 26 \\
\hline
\end{tabular}

Table 2. The number of phases for 5 most common AETs in Double AET

\begin{tabular}{ccc}
\hline Structure Type & AET(double) & Number of Phases \\
\hline $\mathrm{CrSSi}_{3}$ & $12 \cdot \mathrm{a}, 14-\mathrm{a}$ & 66 \\
$\mathrm{BiI}_{3}$ & $2 \# \mathrm{a}, 6 \cdot \mathrm{a}$ & 33 \\
$\mathrm{FeF}_{3}$ & $2 \# \mathrm{a}, 6-\mathrm{a}$ & 33 \\
$\mathrm{AlCl}_{3}$ & $2 \# \mathrm{a}, 6-\mathrm{a}$ & 32 \\
$\mathrm{UCl}_{3}$ & $3 \# \mathrm{a}, 9-\mathrm{a}$ & 29 \\
\hline
\end{tabular}




\section{3. 結果・考察}

Fig.2は Table1 で挙げた各結晶構造に対する AET を、x,y 軸が $\mathrm{MN}$ からなるマトリックスに表示したものであり、元素 $\mathrm{AB}_{3}$ に対 してx 軸（横方向）が $\mathrm{B}$ の元素、y 軸（縦方向）が $\mathrm{A}$ の元素を表 している。また対応する（A，B）にはそれぞれの化合物における AETをマークしている。

まず、 $\mathrm{AB}_{3}$ の $\mathrm{B}$ に着目すると周期律表で、9 族、10 族、13 族、 14 族に 12-b、12 族に 14-d、1 族、2 族に 12-d の各 AET が頱䇣に 現れている。次に $\mathrm{AB}_{3}$ の $\mathrm{A}$ に着目すると周期律表で、3族、4族、 5 族、13 族に 12-b、2 族、3族に14-b、8族、15族に12-d の AET がそれぞれ頉䇣に現れている。

1:1 の元素で、軸が MNに対しての 12·b, 12-d, 14-b のAETを持 つマトリックスを表示すると Fig.3 のように表される。Fig.2 と Fig.3 を比较すると、Fig.2 では 12-b の AET が、Fig.3 では 14-b のAET が覑慗に現れることがわかる。

1:3の化合物では、 single AET に含まれる化合物の数は 1:3 化合 物全体の 4 割程度であり、Tabel 1 の 3 種類のAET の合計は single AET の約 8割である。この状况は、1:1の化合物に比べ、1:3の化 合物は特定の構造への集中の度合いが高いと言える。

さらに、1:3 の化合物では、成分比の大きいほうの原子によりそ のAET が決められている傾向が大きい。これは、MNの小さい元 素に対しても成り立っている。このことは、Villars 等が $1: 1$ 化合物 に対して用いた MN の最大值を一方の軸としたマッピングが、こ の 1:3 化合物に対しては有効でないことを示している。

また、今回詳練は述へなかったが MN が 5〜 50 程度の領域に、 化合物がほとんど存在しないのも、1:3の特徵である。

今可取り上げた 3 種類の AET(12-b,12-d,14-b)において、1:1 化 合物では 14-b という AET が主に実現されていたが、1:3化合物で は 12-bが主に実現されており、これら 2 種の化合物の AET マッ プを統一的に理解寸ることは難しい。しかしながら、1:3 化合物に おいてもこれまでの $1: 1$ 化合物同様、各AETがマップ上にそれな りの領域を持って出現している。すなわち、1:1 の場合と類以の軸 変換を行うことにより、より明確な規則性の発見・提示が行える可 能性はある。

\section{4.まとめ}

今回、1:3 化合物を対象とした AET マップを作成することによ り、AET と構成元素の関係をマップ上での領域として示し、そこ に成分比の大きな方の元素により棈造が支配されていることを示 した。マップの詳細については1:1化合物との相違点も見られるが、 $\mathrm{MN}$ を軸の基本としたこのようなマップ作成が、規則性染索の一つ の手法として有効であるといえる。

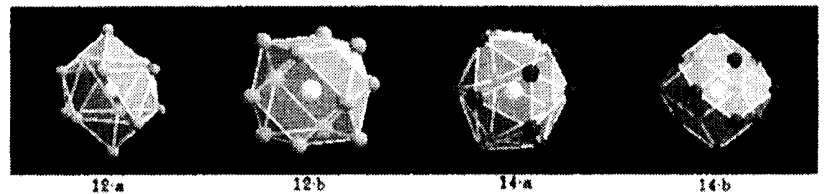

Fig. 1. Typical AET structure;s: (a) 12-a, (b) 12-b, (c) 14-a and (d) 14-b.

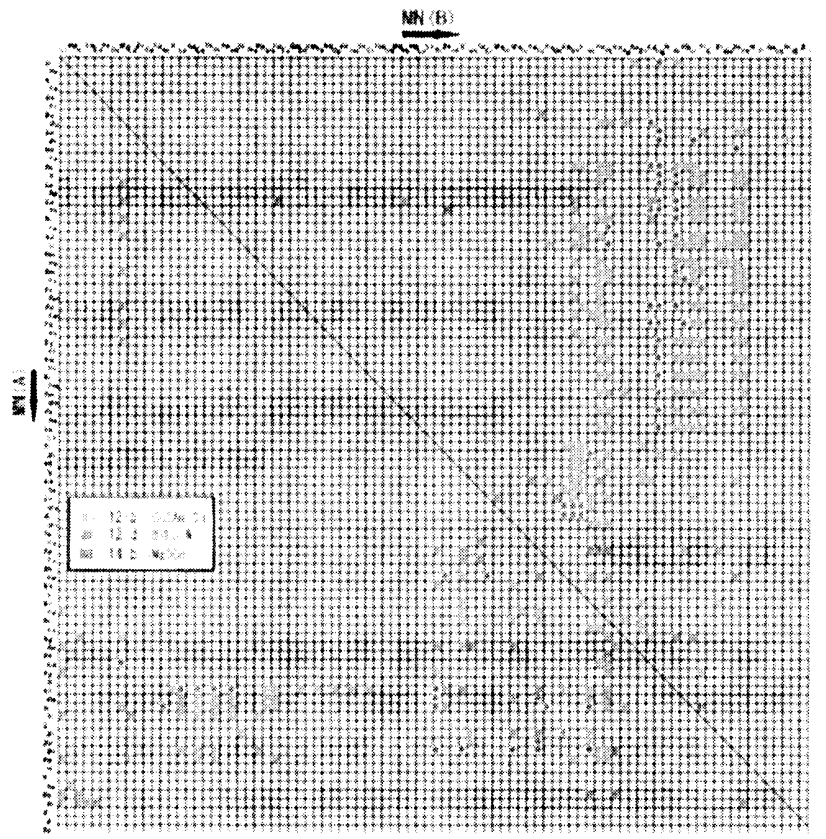

Fig. 2 AET Matrix (3 most common AETs) of single AET in 1:3 stoichiometry compounds $\left(\mathrm{AB}_{3}\right)$. The origin is in the up-left corner. The vertical and horizonta axis are $\mathrm{MN}$ of $\mathrm{A}-\mathrm{atom}$ and $\mathrm{B}-\mathrm{atom}$, respectively.

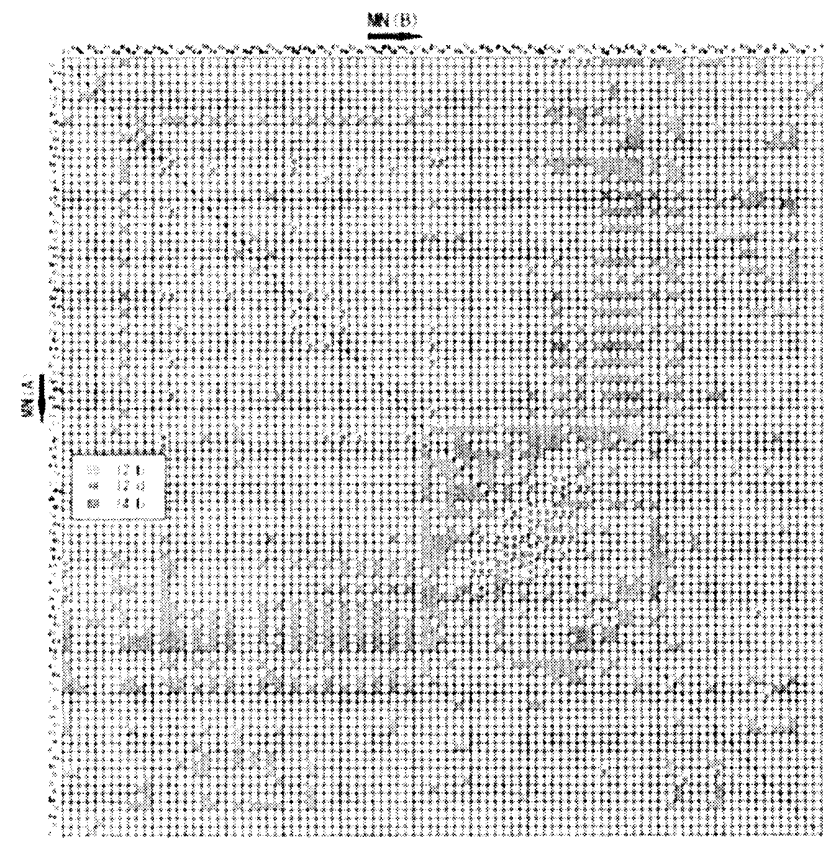

Fig. 3. AET Matrix of single AET in 1:1 stoichiometry compounds (AB) for 3 AETs same as in Fig. 1. The definition of axes is alas same as in Fig. 2

参考文献

[1] P. Villars , K. Cenzual , J. Daams , Y. Chen , S. Iwata, J. Compounds, 2003 , in print.

[2] D.G. Pettifor, Solid State Commun.,51, pp.31-34, 1984.

[3] P. Villars, F. Hulliger, J. Less-Common Met., 132, pp.289-315, 1987.

[4] 陳迎等, 物質材料データベース PAULING FILEに基づい二 元系化合物原子配固パターンの規則性の抽出，第 11 回情報知嬂 学会研究報告会概要集, 2003.

[5] P. Villars, M. Berndt, S. Iwata at el., PAULING FILE CDROM, Binares Edition, 2002. URL: http://www.paulingfile.ch. 